\title{
Addressing Skills Shortages and Hard-to-Fill Vacancies in the Hospitality Sector by Creating Job Opportunities for Youth - Case Study of Red Sea Resort Hotels
}

\author{
Yasser Ibrahim* \\ *Faculty of Tourism and Hotel Management, Helwan University
}

\begin{abstract}
This paper aims to identify the skills shortages and the hard-to-fill vacancies in the Red Sea resort hotels. The study highlights the issues that create a mismatch between the abundant jobs available for young people throughout the hospitality sector, and youth awareness of those jobs and their readiness for them. It also identifies the barriers that constrain new applicants, especially youth, from accessing relevant jobs. Data for this study was collected via a questionnaire survey with representatives from a convenience sample of 38 resort hotels in the Red Sea Governorate. Results revealed that the vast majority of hotels experienced difficulties in recruiting entry level staff, and they continue to suffer from staff shortage in some positions with stewards came at the top of the list, followed by housekeepers, kitchen staff, and then the restaurant service staff. The low wages offered are found to be the highest barrier for youth to get a job in the Red Sea resort hotels. This was followed by the youth's poor attitude to work, youth's poor customer-service skills, and the lack of relevant technical skills. After challenges in the skills shortages in the sector were clearly identified, the study proposes some recommendations for hospitality employers to attract, recruit, employ and retain labor especially from youth through the inclusion of youth development programs into their human resource activities.
\end{abstract}

Keywords: Skills shortages, hard-to-fill vacancies, hospitality sector.

\section{Introduction}

Recently, the global hospitality industry has experienced severe competition in recruiting new staff due to several factors, including high turnover rates and labor shortages (Zopiatis et al., 2014). It is obvious that skills shortages lead to bad economic performance of the firms. Moreover, many problems will arise as a result of skills shortages such as poor customer service, delays in developing new products and services, and increasing operating costs (Marchante et al., 2006). Willie et al. (2017) pointed out that, the hotel industry is characterized by the presence of low salaries, long and unsociable working hours, poor career structures, inconvenience shift patterns, high levels of labor turnover and difficulties in recruitment and retention of skilled staff. These problems significantly contribute to the barriers of attracting skilled labor and to upgrading the workforce's skills. Such environment has created a "turnover culture" in the hospitality industry that forces employers to go through consistent and costly recruiting efforts (McGinley et al., 2017). 
Surprisingly with relatively high unemployment rate in Egypt, according to the World Bank (2017) unemployment rate reached $12.1 \%$ in 2016, the hotel industry suffers also from skill shortages that lead to many hard-to-fill vacancies and tough competition in recruiting new staff. The hospitality industry in Egypt is considered a significant contributor to the country's economy and its outlook is positive. However, despite its contribution, there are some significant challenges too; the hospitality sector in particular suffer from skill shortages for a variety of reasons, including low-level interest in working in the industry owing to its relatively poor image arising from a long working hours and low pay (ENCC, 2013). The UNESCO Global Monitoring Report (2012) revealed that skill availability is insufficient to meet Egypt's tourism needs. It explained that, in 2010, at tourism's peak, all hospitality sectors experienced shortages. Moreover, since the year 2011, all tourism destinations in Egypt have seen decline in tourist arrivals and a significant number of hotels have closed their operations. As a result, many of experienced and well trained hotel staff left their jobs.

The greatest threat to Egypt's tenuous economic progress is unemployed youth. Unemployment enforced many young people to accept low productivity, low paid and insecure jobs, far below their capabilities. On the other hand, tourism and hospitality industry is extremely labor intensive and a significant source of employment. It is among the world's top creators of jobs and allows quick entry into the workforce for young people. For instance, employment in the international tourism industry accounted for more than 260 million jobs in 2012 (8.7\% of the overall number of direct and indirect jobs or one in every eleven jobs). Employment in this industry is normally oriented towards individuals aged under 35 years with half of them are only 25 years or under, and a large number are women (ILO, 2010; 2015). In Egypt, according to WTTC (2017) the total contribution of travel \& tourism to employment in 2016, including jobs indirectly supported by the industry was $6.6 \%$ of total employment $(1,763,000$ jobs).

It seems paradoxical that the hospitality industry in Egypt suffers skills shortage with numerous hard-to-fill vacancies while a large number of youth is unemployed. This situation may arise from the fact that applicants lack employability skills or the poor image of the industry. Sobaih (2015) indicated that employers in the Egyptian hospitality industry argued that applicants are often not prepared for the workplace and lack the necessary working skills. Obviously there is a mismatch between the numerous good jobs available for young people throughout the hospitality sector, and young people's awareness of those jobs and their readiness for them. If that skills gap can be bridged by a serious of community and industry commitment to supporting youth, the rewards will be massive for both youth and hospitality businesses. As the hospitality industry in Egypt needs to recruit young people, and young people need jobs. The solution seems simple enough, but in reality, as industry employers know, recruiting and retaining talent youth with the necessary skills can be a substantial challenge. 
Based on the pervious discussion, this paper explains how the hospitality sector can begin to meet that challenge. Therefore the purpose of this research is to analyze the factors involved in the existence of hard-to-fill vacancies and skills shortages in the hospitality sector focusing on the Red Sea area. The study of skills shortages within the hotel sector in Egypt is not very common; thus, the present study helps to fill this gap in the current literature. To achieve this objective, the study first will define job opportunities in the resort hotels in the Red Sea area. Then it will identify the barriers that constrain new applicants, especially youth, from accessing relevant work skills and jobs in hotels. After that it will propose recommendations for hospitality practitioners to attract employ and retain skilled workers especially from youth to overcome the problem of skills shortages.

\section{Methodology}

A questionnaire survey was developed to collect related data from employers (resort hotels in the Red Sea Governorate). The questionnaire was developed based on extensive review of relevant literature and the guide to assessing and designing workforce tourism development programs developed by Bonifaz et al. (2010) that was supported by resources from USAID and Global Sustainable Tourism Alliance (GSTA).

The research tool intended to help assessing human resources opportunities and constraints in the hospitality industry in the Red Sea Governorate. It is designed to assess the attitudes of hospitality employers towards youth as a potential workforce in the hospitality sector, and to define the job opportunities for youth in the investigated sector. The questionnaire form was divided into four sections. Section one asks about the profile of the respondent from the hotel, section two asks about the profile of the hotel, section three includes recruitment questions and section four is about youth training and education. The developed questionnaire was pilot tested with some experts in the industry and following pre-testing, minor amendments were made.

Personal interviews were conducted, during April and May 2017, with respondents to complete the questionnaire forms. Data collection using personal interviews was highly useful, as this allowed in-depth investigation of the key issues related to skills shortage in the hospitality sector in the Red Sea Governorate. The study used a convenience sample of 38 resort hotels. The sampled hotels are from the first class hotels, the names of the resort hotels are presented in Table 1.

\section{Results}

\section{Profile of the respondents}

All respondents were from the human resources department and the training department (see Table 1). Eighty one percent of the respondents were males, and only $19 \%$ were females. All the respondents had university degrees. The age of the respondents ranged between 30 to 45 years old. 


\section{Profile of the sampled hotels}

The analysis of data collected from the questionnaire survey revealed that $75 \%$ of the sampled hotels have been in operation in the Red Sea Governorate for more than 11 years while only $25 \%$ of them have started their operation between 6 to 10 years ago.

The data analysis revealed that resort hotels in the Red Sea area employ only full time staff, they do not employ part-time or seasonal staff at all, and just few hotels offer training opportunities to interested youth. The analysis also revealed that the vast majority of employees are males. On average the male staff consisted nearly $97 \%$ of the total staff in the sampled hotels. This results is in agreement with the findings of many studies on employment in this area due to the living conditions in remote area (i.e., Sobaih, 2015).

Table 1: Participated hotels and the positions of respondents

\begin{tabular}{|c|c|c|}
\hline & Hotel Name & $\begin{array}{l}\text { Position of } \\
\text { respondent }\end{array}$ \\
\hline 1. & Serenity Makadi Heights & HR Coordinator \\
\hline 2. & Continental Hotel Hurghada (Moevenpick) & HR Specialist \\
\hline 3. & Sun Rise Garden Beach Resort & HR Coordinator \\
\hline 4. & Jaz Makadi Star \& Spa & Training Specialist \\
\hline 5. & Makadi Palace Hotel & $\begin{array}{l}\text { Assistant HR } \\
\text { Manager }\end{array}$ \\
\hline 6. & Pyramisa Resort Sahl Hasheesh & HR Coordinator \\
\hline 7. & Sonesta Pharaoh Beach Resort & Training Specialist \\
\hline 8. & Magawish Swiss Inn Resort & HR Coordinator \\
\hline 9. & Oberoi Sahl Hasheesh & $\begin{array}{l}\text { Assistant HR } \\
\text { Manager }\end{array}$ \\
\hline 10. & Arabella Azur Resort & Training \\
\hline 11. & Club Azur Resort (Labranda Club Makadi) & HR coordinator \\
\hline 12. & Coral Beach Hurghada Hotel (ex. Rotana) & $\begin{array}{l}\text { Assistant HR } \\
\text { Manager }\end{array}$ \\
\hline 13. & Grand Hotel Hurghada & HR Manager \\
\hline 14. & Mercure Hurghada Hotel & HR Manager \\
\hline 15. & Steigenberger Aqua Magic Hotel & $\begin{array}{l}\text { Assistant HR } \\
\text { Manager }\end{array}$ \\
\hline 16. & Arabia Azur Resort & HR Coordinator \\
\hline 17. & Sea Star Beau Rivage Hotel & $\begin{array}{l}\text { Assistant HR } \\
\text { Manager }\end{array}$ \\
\hline 18. & Holidays Resort & HR Coordinator \\
\hline 19. & Hilton Hurghada Plaza & HR Manager \\
\hline 20. & Grand Makadi Hotel & HR Supervisor \\
\hline 21. & Dana Beach Resort & Training Coordinator \\
\hline
\end{tabular}




\begin{tabular}{|c|c|c|}
\hline 22. & Old Palace Sahl Hasheesh & HR Manager \\
\hline 23. & Marriott Beach Resort & HR Coordinator \\
\hline 24. & Sun Rise Crystal & HR Manager \\
\hline 25. & Desert Rose Resort Hurghada & $\begin{array}{l}\text { Assistant HR } \\
\text { Manager }\end{array}$ \\
\hline 26. & Sun Rise Holidays & Training Manager \\
\hline 27. & Mina Mark Resort Hurghada & HR Manager \\
\hline 28. & Sunny Days El Palacio & $\begin{array}{l}\text { Assistant HR } \\
\text { Manager }\end{array}$ \\
\hline 29. & Titanic Beach Resort Hurghada & HR Manager \\
\hline 30 . & Grand Plaza Hurgaha & $\begin{array}{l}\text { Assistant HR } \\
\text { Manager }\end{array}$ \\
\hline 31. & Fort Arabesque & HR Manager \\
\hline 32. & Radisson Blu El Kusir & HR Manager \\
\hline 33. & Steigenberger Aldou & Director of L \& D \\
\hline 34. & Makadi Spa & HR Manager \\
\hline 35. & Sun Rise Select & $\begin{array}{l}\text { Assistant HR } \\
\text { Manager }\end{array}$ \\
\hline 36. & Golden 5 & HR Manager \\
\hline 37. & Le Pacha Resort & $\begin{array}{l}\text { Assistant HR } \\
\text { Manager }\end{array}$ \\
\hline 38. & Sunny Days Palma De Mirette & $\begin{array}{l}\text { Assistant HR } \\
\text { Manager }\end{array}$ \\
\hline
\end{tabular}

Regarding the age distribution of the staff in the sampled hotels, Figure 1 shows that the age of the majority of staff in the hotels are less than 30 years old. As depicted in the figure $59 \%$ of the staff is less than 30 years old, with nearly half of them less than 25 years. On average, $27 \%$ of staff is between 31 to 40 years old. This was followed by groups aged from 41 to 50 years old (11\%). Only $3 \%$ of the staff is more than 51 years old. The age distribution of the staff in the investigated area is in the same pattern as the international tourism employment trends as previously mentioned.

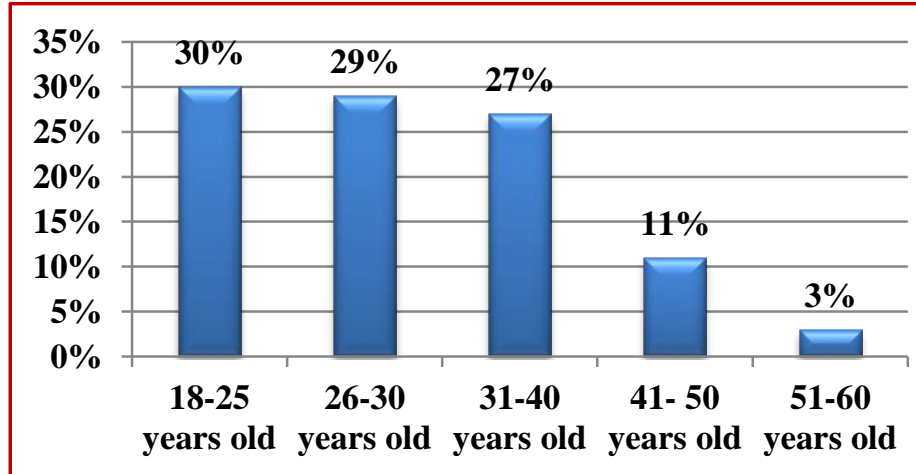

Figure 1: The age distribution of workface in the sampled hotels 
Respondents were asked to indicate the degree their businesses anticipate growth in staff in the next year. Overall, employers seemed quite optimistic, with $88 \%$ anticipating growth in full-time employees, as compared to only $12 \%$ who are unsure of the situation of the next year (see figure 2). The respondents' predictions are likely based upon the staff shortage they already suffering now, in addition to growth that they are experiencing within their businesses, as well as data that indicates that tourism and the economy in general in the Red Sea area are expanding.

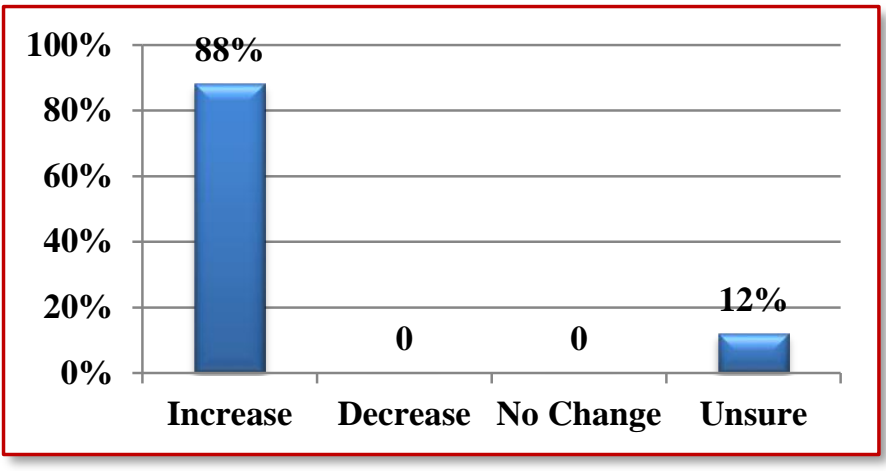

Figure 2: Anticipation of the change of staff numbers over the next year

When respondents were asked about which part of the country normally their staff come from. They indicated that the majority of their workforce (77\%) comes from Upper Egypt, this may be due to the relative proximity. On the other hand, they indicated that only $2 \%$ of their workforce comes from the Red Sea Governorate and $20 \%$ comes from other parts of the country, while only $1 \%$ foreigners (see Figure 3).

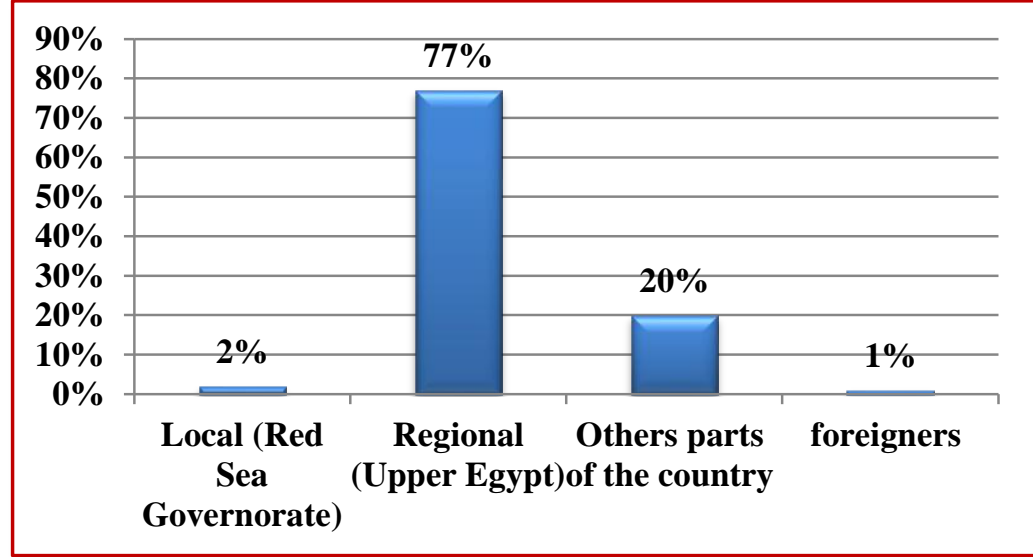

Figure 3: Distribution of workforce according to the place they came from

\section{Recruitment questions}

Respondents were asked about the current entry level jobs that are available in their hotels at the time of study. It is noted from the results that there is a shortage of the workforce in the restaurant service staff, followed by stewards, kitchen staff and housekeeping staff in a descending order. All the sampled hotels suffer from the shortage of staff even with the hotels occupancy levels tend to be below average. 
Respondents were requested to indicate the level of importance of skills/knowledge that new inexperienced youth should have to be recruited by the hotel. They were asked to rate the importance of the skills on a scale from 1 (not important) to 5 (very important). Table 2 shows the results obtained from the analysis of the questionnaire. Figure (4) ranks the skills/knowledge by its importance when hiring inexperienced youth by hotels. The availability of references came at the top of the list followed by appearance/first impressions, certification/accreditation, and English language skills. Surprisingly, that relevant hospitality training and education came at the bottom of the list.

Table 2: The importance of skills/knowledge when hiring inexperienced youth

\begin{tabular}{|c|c|c|c|c|c|c|}
\hline Knowledge and skills & 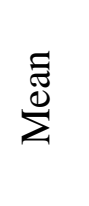 & 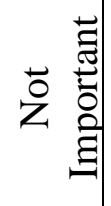 & 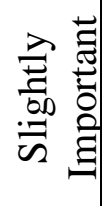 & 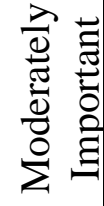 & 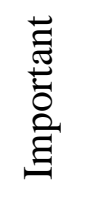 & 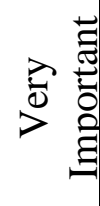 \\
\hline & & $\%$ & $\%$ & $\%$ & $\%$ & $\%$ \\
\hline Appearance/First Impressions & 4.12 & 0 & 4.2 & 12.5 & 50.0 & 33.3 \\
\hline Certification/Accreditation & 4.00 & 0 & 4.2 & 4.2 & 79.2 & 12.5 \\
\hline Communication Skills & 3.79 & 0 & 12.5 & 12.5 & 58.3 & 16.7 \\
\hline English Language Skills & 3.88 & 0 & 0 & 25.0 & 62.5 & 12.5 \\
\hline Other Foreign Language Skills & 2.96 & 12.5 & 16.7 & 37.5 & 29.2 & 4.2 \\
\hline Performance at Interview & 3.88 & 0 & 8.3 & 20.8 & 45.8 & 25.0 \\
\hline Personality \& Enthusiasm & 3.67 & 0 & 4.2 & 41.7 & 37.5 & 16.7 \\
\hline Professionalism of CV & 3.71 & 4.2 & 4.2 & 25.0 & 50.0 & 16.7 \\
\hline References & 4.75 & 4.2 & 0 & 0 & 8.3 & 87.5 \\
\hline Hospitality Education & 3.25 & 4.2 & 29.2 & 16.7 & 37.5 & 12.5 \\
\hline Hospitality Training & 3.38 & 4.2 & 20.8 & 20.8 & 41.7 & 12.5 \\
\hline
\end{tabular}

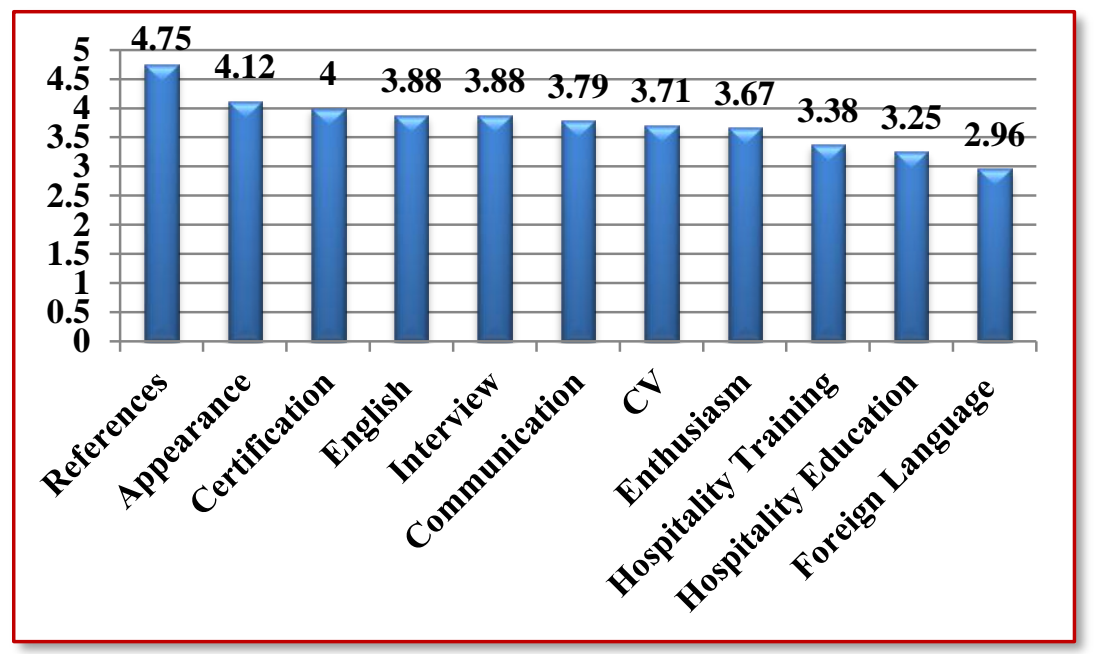

Figure 4: Rank order by mean value of skills/knowledge by importance 
Respondents were asked if their hotels are currently experiencing, or have experienced, any difficulties filling entry level job vacancies in the past 12 months. Results revealed that the vast majority of hotels $(88 \%)$ indicated that they experienced difficulties in recruiting entry level staff during the last year, and they continue to suffer from staff shortage in some positions as indicated in the previous sections of the study.

According to the proceeding questions, respondents indicated the level of difficulty they experience in recruiting entry level positions. Table 3 shows the results obtained from the analysis of the survey. Figure 5 depicts the rank of entry level positions based on the difficulty level hotel experience in recruiting these jobs. Stewards came at the top of the list, followed by housekeepers, kitchen staff, and then the restaurant service staff.

Table 3: The level of difficulty in recruiting entry level positions

\begin{tabular}{|l|c|c|c|c|}
\hline \multicolumn{1}{|c|}{ Occupation } & Mean & $\begin{array}{c}\text { Not } \\
\text { Difficult }\end{array}$ & $\begin{array}{c}\text { Moderately } \\
\text { Difficult }\end{array}$ & $\begin{array}{c}\text { Very } \\
\text { Difficult }\end{array}$ \\
\hline Commis (cook) & & $\%$ & $\%$ & $\%$ \\
\hline Commis (bakery \& pastry cook) & 1.92 & 41.7 & 25.0 & 33.3 \\
\hline Waiters & 1.75 & 45.8 & 33.3 & 20.8 \\
\hline Bartenders & 1.75 & 41.7 & 41.7 & 16.7 \\
\hline Stewards & 2.67 & 12.5 & 8.3 & 79.2 \\
\hline Housekeepers (room attendant) & 2.29 & 16.7 & 37.5 & 45.8 \\
\hline Front desk agents & 1.38 & 75.0 & 12.5 & 12.5 \\
\hline Reservations (sales agents) & 1.33 & 79.2 & 8.3 & 12.5 \\
\hline Bellman /captain & 1.25 & 83.3 & 8.3 & 8.3 \\
\hline
\end{tabular}

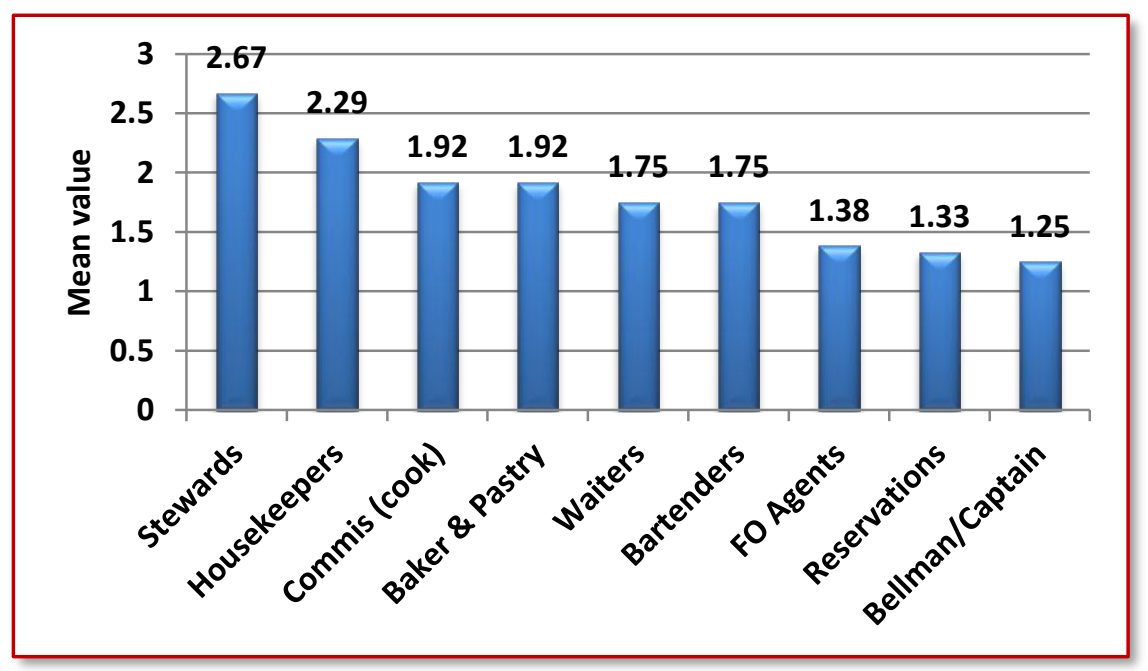

Figure 5: Ranking of entry level positions based on difficulty in recruiting 
In regard to the main obstacles in recruiting young qualified employees for entry level positions, the respondents evaluated each reason or obstacle on a 5-point scale ranged from 1 (strongly disagree) to 5 (strongly agree). Table 4 shows the obtained results while, Figure 6 depicts the rank order of the obstacles in descending order. Higher wages offered by other employers came as the main obstacle (mean $=3.46)$, followed by general lack of applicants interested in this type of work (mean $=3.42$ ), too much competition for staff from other employers in the industry (mean $=3.21)$, lack of applicants with the appropriate skills and work experience (mean $=3.08$ ).

Table 4: Obstacles in recruiting young qualified employees

\begin{tabular}{|c|c|c|c|c|c|c|}
\hline $\begin{array}{c}\text { Obstacles in recruiting young qualified } \\
\text { employees }\end{array}$ & $\stackrel{\Xi}{\Xi ँ ~}^{\tilde{\Xi}}$ & 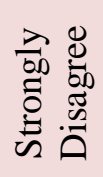 & $\begin{array}{l}\stackrel{0}{D} \\
\stackrel{D}{0} \\
\ddot{D} \\
\ddot{D}\end{array}$ & 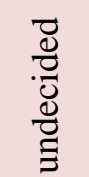 & 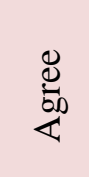 & 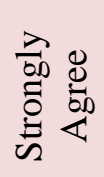 \\
\hline & & $\%$ & $\%$ & $\%$ & $\%$ & $\%$ \\
\hline Higher wages offered by other employers & 3.46 & 20.8 & 12.5 & 0 & 33.3 & 33.3 \\
\hline $\begin{array}{l}\text { Job involves shift work or unsociable } \\
\text { hours }\end{array}$ & 1.75 & 62.5 & 16.7 & 4.2 & 16.7 & 0 \\
\hline $\begin{array}{l}\text { General lack of applicants interested in } \\
\text { this type of work }\end{array}$ & 3.42 & 16.7 & 16.7 & 4.2 & 33.3 & 29.2 \\
\hline $\begin{array}{l}\text { Lack of applicants with the appropriate } \\
\text { skills }\end{array}$ & 3.08 & 12.5 & 25.0 & 20.8 & 25.0 & 16.7 \\
\hline Lack of appropriate work experience & 2.96 & 16.7 & 29.2 & 12.5 & 25.0 & 16.7 \\
\hline Poor image of the occupation/ industry & 2.96 & 25.0 & 16.7 & 12.5 & 29.2 & 16.7 \\
\hline Remote location/Poor transportation & 2.00 & 45.8 & 25.0 & 16.7 & 8.3 & 4.2 \\
\hline Seasonal Work & 1.96 & 50.0 & 16.7 & 20.8 & 12.5 & 0 \\
\hline $\begin{array}{l}\text { Too much competition for staff from } \\
\text { other employers in the industry }\end{array}$ & 3.21 & 16.7 & 16.7 & 20.8 & 20.8 & 25.0 \\
\hline $\begin{array}{l}\text { No data available about hospitality job } \\
\text { seekers }\end{array}$ & 2.42 & 41.7 & 16.7 & 12.5 & 16.7 & 12.5 \\
\hline Lack of HR / Hiring Experience & 1.29 & 79.2 & 16.7 & 0 & 4.2 & 0 \\
\hline Too many vacancies to handle & 1.25 & 83.3 & 12.5 & 0 & 4.2 & 0 \\
\hline
\end{tabular}

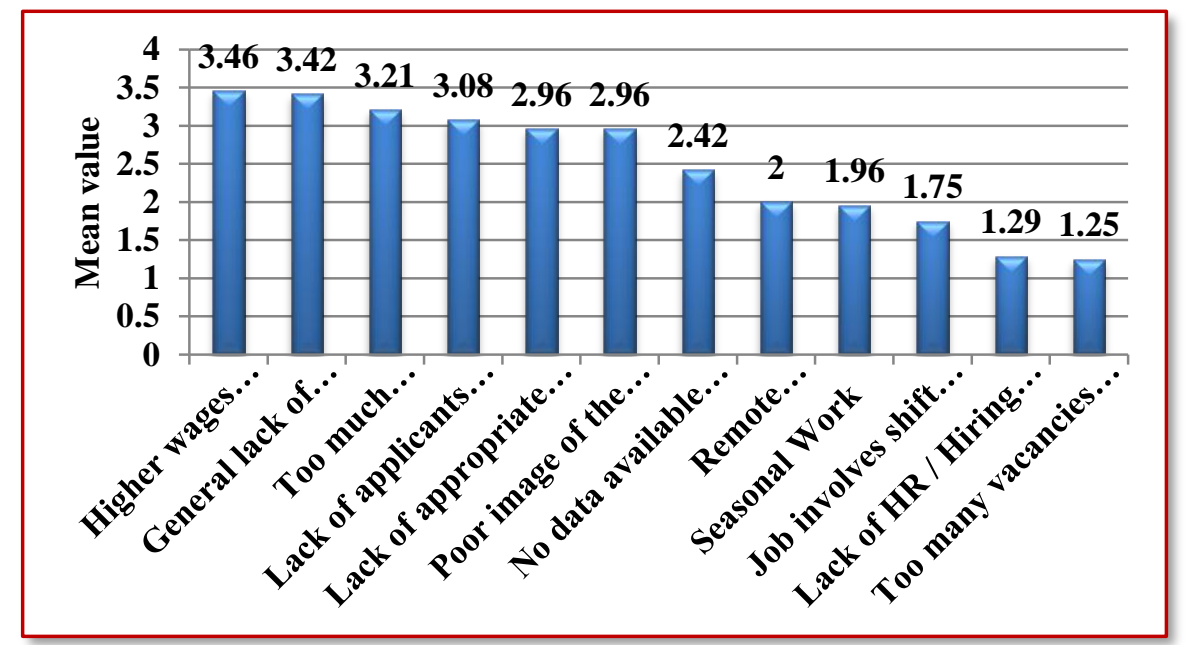

Figure 6: Ranking of the obstacles in recruiting entry level positions 


\section{Youth Training and Education}

Respondents were asked about the percentage of applicants from youth that meets their hotels' entry level standards. They indicated that about $70 \%$ of youth applying for entry level jobs in their hotels are accepted or just meet their requirements. They also indicated that the majority of hotels (88\%) are interested in offering two to three months internships/training for out-of-school or unemployed youth.

Respondents were asked to indicate their opinion about the technical skills of the new youth hired in different positions. Their evaluation are identified on a 5point scale ranging from 1 (very poor) to 5 (very good). Table 5 shows that front desk agents, reservation agents and concierge staff came at the top of the list with relatively high skill levels. Normally, new staff hired on these positions possesses relatively good skills, the mean value for the three positions was (4.17). On the other hand, respondents indicated that stewards were normally hired with skills below average (mean $=2.79$ ). They also indicated that the skills of housekeepers and waiters hired by the hotels were average, mean values equal to 3.58 and 3.29 respectively.

Table 5: Evaluation of the technical skill levels of new youth hires

\begin{tabular}{|c|c|c|c|c|c|c|}
\hline Position & $\stackrel{\Xi}{\stackrel{\Xi}{\Xi}}$ & $\begin{array}{l}\lambda \overrightarrow{0} \\
>0 \\
>0\end{array}$ & $\begin{array}{l}\dot{0} \\
\stackrel{0}{0}\end{array}$ & : & $\begin{array}{l}\overline{8} \\
8 \\
0\end{array}$ & $\begin{array}{l}\vec{D} \\
\overline{0} \\
>0 \\
>0\end{array}$ \\
\hline & & $\%$ & $\%$ & $\%$ & $\%$ & $\%$ \\
\hline Commis (cook) & 3.71 & 0 & 4.2 & 29.2 & 58.3 & 8.3 \\
\hline Commis (Baker \& Pastry) & 3.71 & 0 & 4.2 & 29.2 & 58.3 & 8.3 \\
\hline Waiters & 3.29 & 0 & 20.8 & 37.5 & 33.3 & 8.3 \\
\hline Bartenders & 3.50 & 0 & 12.5 & 33.3 & 45.8 & 8.3 \\
\hline Stewards / Dishwashers & 2.79 & 12.5 & 37.5 & 12.5 & 33.3 & 4.2 \\
\hline Housekeepers (Room attendant) & 3.58 & 0 & 20.8 & 16.7 & 45.8 & 16.7 \\
\hline Front Desk Agents & 4.17 & 4.2 & 4.2 & 4.2 & 45.8 & 41.7 \\
\hline Reservations Sales Agents & 4.17 & 4.2 & 4.2 & 4.2 & 45.8 & 41.7 \\
\hline Concierges/Bell Captain & 4.17 & 4.2 & 4.2 & 4.2 & 45.8 & 41.7 \\
\hline
\end{tabular}

In regard to the evaluation of the hospitality education and training programs. Respondents indicated that hospitality vocational education and university programs are good in preparing youth for working in the hospitality industry. However, they could not recognize any government training providers, industry training providers or NGO training programs that support the workforce in the hospitality industry.

Respondents' opinions about the barriers that youth face in getting a job in the

Red Sea hotels were evaluated on a four-point scale ranging from 1 (not a barrier) to 4 (great barrier). They ranked the low wages offered in the industry as the highest barrier for youth to get a job in the hotels (see Table 6 and Figure

7). This was followed by the youth's poor attitude to work, youth's poor customer-service skills, then youth's lack of relevant technical skills. 
Table 6: Barriers that youth face in getting a job in the Red Sea hotels

\begin{tabular}{|c|c|c|c|c|c|}
\hline $\begin{array}{l}\text { Barriers that youth face in to getting a } \\
\text { job }\end{array}$ & $\sum_{\Sigma}^{\Xi}$ & 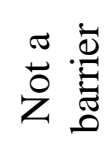 & 葛 & 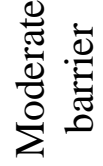 & 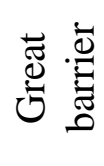 \\
\hline & & $\%$ & $\%$ & $\%$ & $\%$ \\
\hline Youth's lack of good workplace habits & 2.54 & 33.3 & 4.2 & 37.5 & 25.0 \\
\hline Youth's poor attitude & 2.83 & 12.5 & 25.0 & 29.2 & 33.3 \\
\hline Low wages & 3.04 & 8.3 & 12.5 & 45.8 & 33.3 \\
\hline Youth's lack of technical/vocational skills & 2.67 & 16.7 & 20.8 & 41.7 & 20.8 \\
\hline Youth's poor customer-service skills & 2.79 & 12.5 & 29.2 & 25.0 & 33.3 \\
\hline $\begin{array}{l}\text { Youth's lack of accreditation (certificate / } \\
\text { degree) }\end{array}$ & 2.50 & 16.7 & 33.3 & 33.3 & 16.7 \\
\hline Youth's lack of work experience & 2.58 & 12.5 & 33.3 & 37.5 & 16.7 \\
\hline $\begin{array}{l}\text { Geographical location (distance to the } \\
\text { job) }\end{array}$ & 1.58 & 66.7 & 16.7 & 8.3 & 8.3 \\
\hline $\begin{array}{l}\text { Difficult work schedules (long hours, late } \\
\text { shifts) }\end{array}$ & 1.71 & 54.2 & 20.8 & 25.0 & 0 \\
\hline Dangerous or risky work environment & 1.17 & 87.5 & 8.3 & 4.2 & 0 \\
\hline $\begin{array}{l}\text { Discrimination (sex, age, health } \\
\text { conditions, etc.) }\end{array}$ & 1.42 & 79.2 & 8.3 & 4.2 & 8.3 \\
\hline Lack of family connections & 1.58 & 66.7 & 16.7 & 8.3 & 8.3 \\
\hline $\begin{array}{l}\text { Lack of information on employment } \\
\text { opportunities }\end{array}$ & 1.75 & 54.2 & 20.8 & 20.8 & 4.2 \\
\hline Childcare & 1.67 & 70.8 & 4.2 & 12.5 & 12.5 \\
\hline Three-month temporary contracts & 1.42 & 75.0 & 12.5 & 8.3 & 4.2 \\
\hline Lack of foreign language skills & 2.42 & 29.2 & 33.3 & 4.2 & 33.3 \\
\hline
\end{tabular}

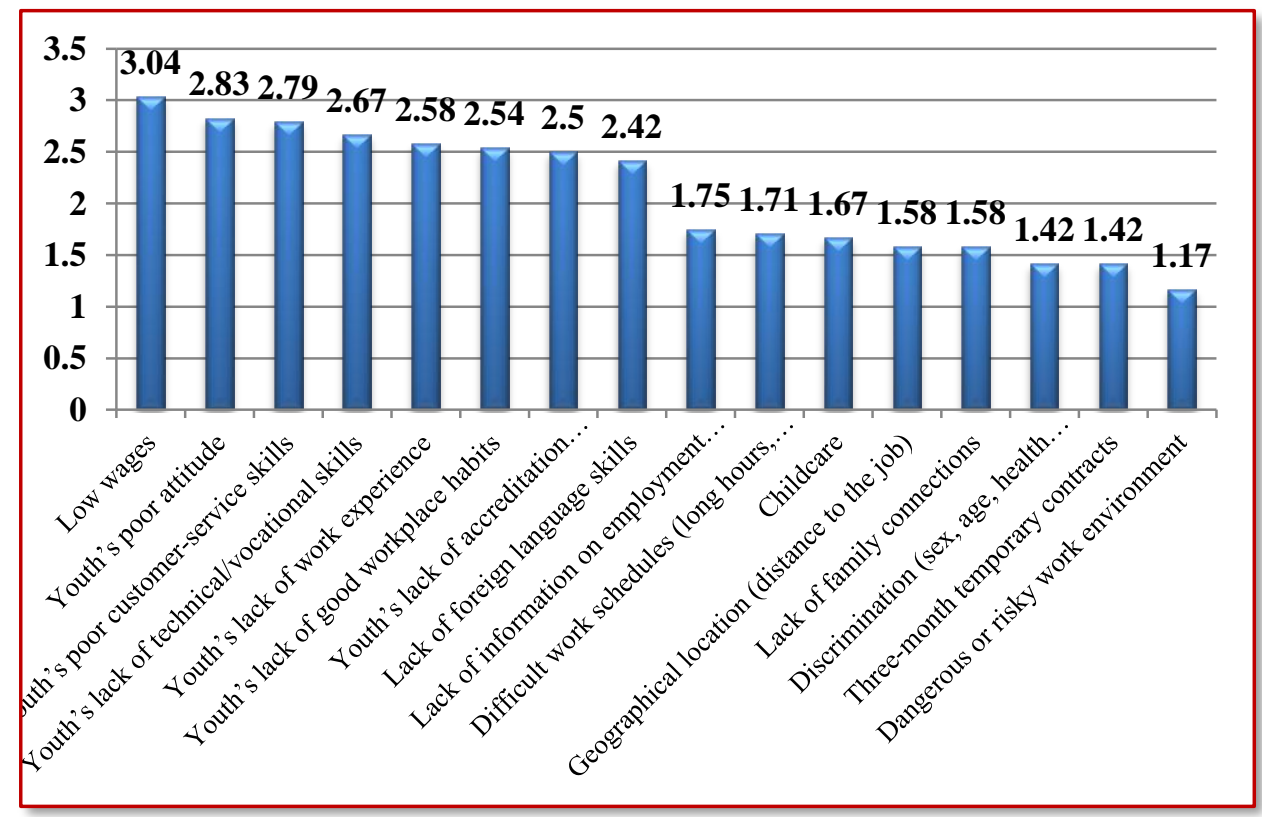

Figure 7: Descending rank of barriers that youth face in getting a job in hotels 


\section{Conclusion and Practical Implications}

The Egyptian hospitality industry is a significant employer and an important contributor to the economy as well. However, this study has highlighted the fact that the hotel sector in particular is challenged by skilled labor shortages. The study identified the hard-to-fill vacancies in the Red Sea resort hotels. The results revealed that the vast majority of hotels experienced difficulties in recruiting entry level staff i.e. stewards, housekeepers, kitchen staff, and restaurant service staff. The study also identified the barriers that constrain youth applicants from accessing relevant jobs. The low salaries offered by the industry are found to be the highest barrier for them in getting a job in the investigated area.

As challenges in the skills shortages in the investigated sector made clear, the study recommends that the industry employers can attract, employ and retain staff from youth through three main activities namely; pre-employment initiatives, on-the-job activities and partnerships.

First, pre-employment activities with the aim of attracting youth to the hospitality industry and helping them qualify for entry-level positions through employability training. This can be done through: 1) Teaching youth about the job market by informing them about the world of work, become employable and how to obtain a job. 2) Establishing internship programs that target youth in the various hospitality educational programs. These internships would introduce them to the numerous types of employment offered in the industry and the education and skills required for each. Moreover, these will enable youth to gain a realistic picture of the day-to-day operations while enlightening possibilities for their future career. 3) Using ICT and blended learning modules will make training on a large scale easier and more affordable to youth. 4) Making preemployment activities appealing to youth. In the same direction, Bohdanowicz and Zientara (2008) argued that today's youth are attracted to hospitality employers who reflect their values especially when these values are core to a company's business model.

Second activity, on-the-Job youth training initiatives, these investments in youth aim to retain talented employees in the workforce and gain a competitive advantage. This can be done through: 1) Offering flexible and convenient opportunities for training and apprenticeships in the industry for youth. 2) Engage youth on the job as they can provide employers with important information about youth development, new ways to recruit and retain young staff and innovative ways to deliver learning and training opportunities.

For example, Barron (2008) argued that engaging youth would reveal generational concerns that may predict future business trends, such as how to appeal to young adult guests; developing or applying technologies as social media, or other innovations; youth values and community needs that could be addressed through community engagement programming; and meaningful ways to acknowledge youth for their contributions on and off the job. 
Third, partnerships, partnering with educational and training institutions would help hospitality employers ensure that youth learn about industry careers and possess the needed skill set for hospitality jobs. Employers can use growth projections to help partners prepare the required workforce for tomorrow's jobs. Working in business clusters - formal organizations in a community that share professional interests - presents another opportunity for local and international firms with shared business interests to make investments that result in the enhanced competitiveness of all members. Working together in business clusters can make the best use of training, resulting in economic gains for individual businesses, the cluster, youth and the community as a whole. Clusters can address market failures that impact their businesses, such as inadequate public investment in preparing youth for hospitality jobs.

As, Davidson et al., (2011) indicated that although the hospitality industry regularly collects data on customer preferences, and business trends, it lacks vital information on youth views towards the industry, i.e., how young people and their families view jobs in the sector, why youth enter the industry, and why they leave and how hospitality clusters can be best utilized to realize sustainable gains for youth and employers. It is highly recommended to fill knowledge gaps about the hospitality industry and facilitate policy formation and this could be done through establishing partnerships with hospitality academic and research institutions.

In an effort to attract and retain qualified staff in the dynamic Egyptian hospitality industry, further studies with new strategies and tactics must be carried out. This can only be done through effective communication, cooperation and collaboration between hospitality educational institutions and industry practitioners.

\section{Limitations and Future research}

A comprehensive assessment of hospitality industry skilled labor shortages should include three interrelated components, although each one can be implemented individually. The three components are; assessment of industry demand for workforce skills, assessment of the capabilities of education and training providers to meet industry demand for these skills and assessment of the attitudes and perceptions of young people towards working in the industry. Thus, it is recommended that future studies carry on a comprehensive assessment of this issue.

Furthermore, this study investigated the skills shortages using a sample resort hotels in the Red Sea area. Thus, in the further studies, it is worthwhile investigating this issue in other destinations. 


\section{References}

Barron, P. (2008). Education and Talent Management: Implications for the Hospitality Industry. International Journal of Contemporary Hospitality Management, 20(7), 730-742.

Bohdanowicz, P. and Zientara, P. (2008). Hotel Companies' Contribution to Improving the Quality of Life of Local Communities and the Well-being of their Employees. Tourism and Hospitality Research, 9(2), 147-158.

Bonifaz, A., Hawkins, D. and Israel, R. (2010). Guide to Assessing and Designing Tourism Workforce Development Programs: with a special focus on job and career opportunities for youth. Educational Development Center. Available at: www.equip123.net.

Davidson, M. C. G., McPhail, R. and Barry, S. (2011). Hospitality HRM: Past, Present and Future. International Journal of Contemporary Hospitality Management, 23(4), 498-516.

ENCC "Egyptian National Competitiveness Council" (2013). Refreshed Tourism Strategy (2013-2020) the Way Forward and New Horizons. Available at: http://www.encc.org.eg (accessed 12-8-2017).

ILO "International Labour Organisation" (2010). Developments and challenges in the hospitality and tourism sector, Issues paper for the Global Dialogue Forum for the Hotels, Catering, Tourism Sector, Geneva, 23-24 November.

ILO "International Labour Organisation" (2015). ILO Tourism Activities in Egypt. Available at: http://www.ilo.org. (accessed 1-3-2017).

Marchante, A. J., Ortega, B. and Pagan, R. (2006). Determinants of Skills Shortages and Hard-to-fill Vacancies in the Hospitality Sector. Tourism Management 27, 791-802.

McGinley, S. P., Hanks, L. and Line, N. D. (2017). Constraints to Attracting New Hotel Workers: A Study on Industrial Recruitment. International Journal of Hospitality Management, 60, 114-122.

Sobaih, A. (2015). Hospitality Employment Issues in Developing Countries: The Case of Egypt. Journal of Human Resources in Hospitality \& Tourism, 14(3), 221-243.

UNESCO Global Monitoring Report (2012). Skills Gaps Throughout the World: an analysis for UNESCO Global Monitoring Report. Available at:

unesdoc.unesco.org/images/0021/002178/217874e.pdf (accessed 12-8-2017).

Willie, P.A., Connor, D., Sole, J., Forgacs, G., Grieve, R. and Mueller, J. (2017). Human Capital Challenges in the Hotel Industry of Canada: Finding Innovative Solutions. Worldwide Hospitality and Tourism Themes, 9(4), 402410. 
World Bank (2017). Unemployment. Available at:

https://data.worldbank.org/indicator/SL.UEM.TOTL.ZS?locations=EG (accessed 19-10-2017).

WTTC (2017). Travel \&Tourism Economic Impact 2017 Egypt. Available at: https://www.wttc.org/-/.../economic-impact...2017/egypt2017.pdf (accessed 1910-2017)

Zopiatis, A., Constanti, P. and Theocharous, A. L. (2014). Migrant Labor in Hospitality: The Cyprus Experience. International Journal of Hospitality Management. 37, 111-120.

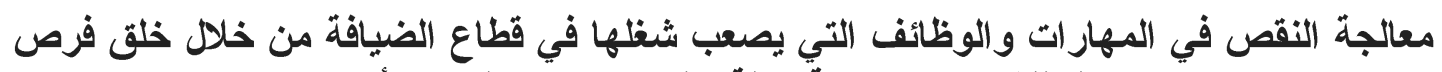
عل للشباب - دراسة حالة على منتجعات البحر الأحمر فئف

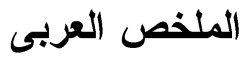

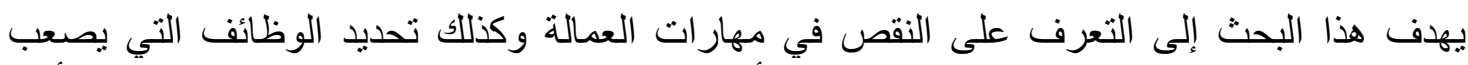

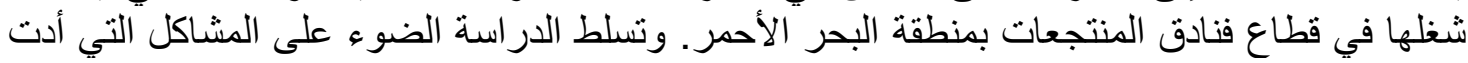

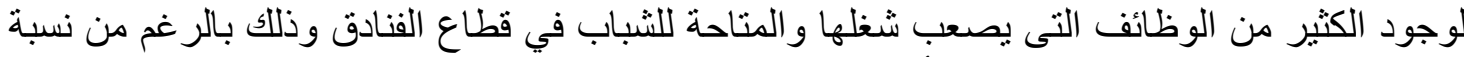

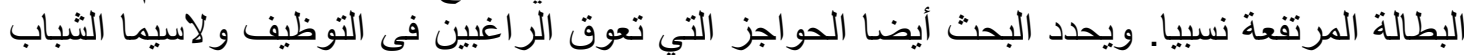

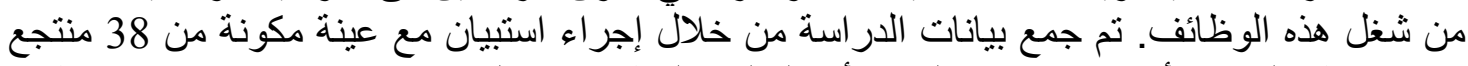

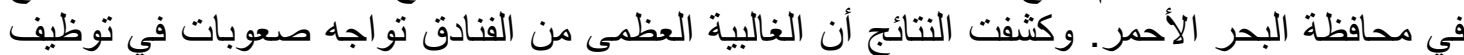

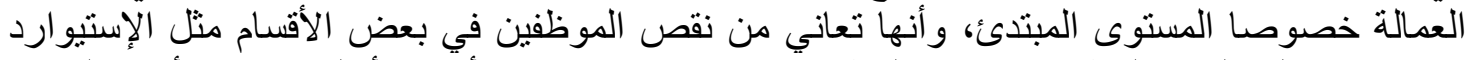

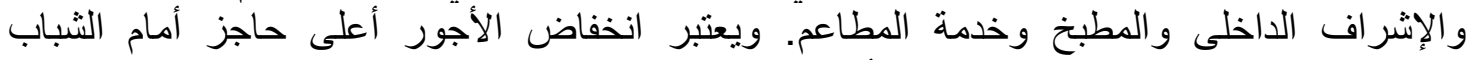

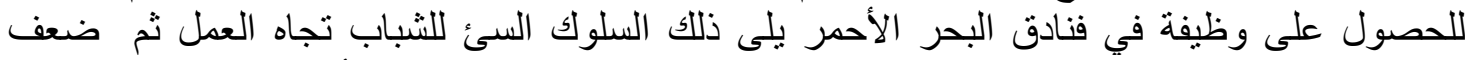

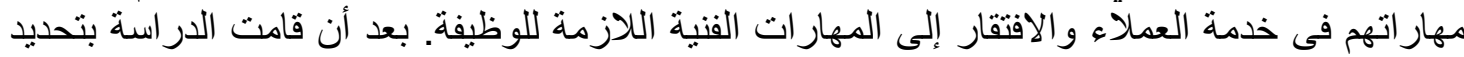

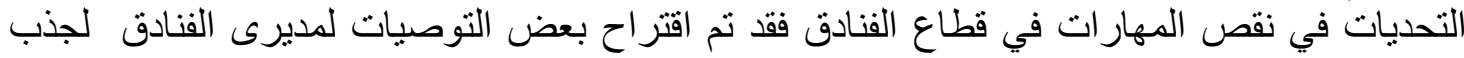

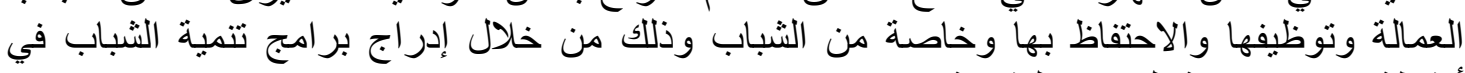
أنشطة وبر امج تنمية المو ارد البشرية بفنادقهر. 